\title{
SIPOS BALÁZS
}

\section{Az angol nyelvü médiatörténet-írásról}

Rövid szemlémben az angol nyelvű médiatörténet-írást szeretném bemutatni - ami azonban lehetetlen vállalkozás. Ha csak a brit (egyesült királysági) vagy az észak-amerikai (egyesült államokbeli) médiatörténet-írást kellene tárgyalni, az is reménytelen vállalkozás lenne, de mert eme diszciplína „lingua francája” az angol, még annál is rosszabb a helyzet, hiszen az angol nyelvü szakirodalom egyúttal a nemzetközi vagy transznacionális médiatörténet-írást képviseli. Igaz ez még akkor is, ha figyelmen kívül hagyjuk például az egyes európai országokban megjelenő angol nyelvű folyóiratokat (például a Lengyel Kommunikációtudományi Társaság negyedévi folyóiratát, a Central European Journal of Communicationt) és szakkönyveket, és közülük csak azokat vizsgáljuk meg, amelyek vagy amelyek szerzői az angol nyelvü nemzetközi térben is szerepet játszanak. E miatt a körülmény miatt elsősorban mégis a brit és az USA-beli szakirodalom helyzetére szükítem vizsgálatomat, bizonyos kérdésekre koncentrálva.

\section{A médiatörténet mint tudományterület}

Az első probléma nyilvánvalóan a médiatörténet mint diszciplína helyzetével, más tudományterületekhez való viszonyával kapcsolatos. James Curran nagyhatású tanulmányában a médiatörténet-írást a médiatudomány (media studies) elhanyagolt nagyszülőjének nevezi, ${ }^{1}$ amihez Siân Nicholas azt füzte hozzá, hogy másfelől pedig ,a történetírás csupán félig elismert ivadéka”. ${ }^{2}$ Ugyanebben a „beszélgetésben" Tom O’Malley az úgynevezett szinoptikus médiatörténetek készítése kapcsán azt is megemlítette: a mai médiatörténészeknek számolniuk kell azzal a fejleménnyel, hogy a politika- és a társadalomtörténet-írás ,számtalan különféle típusú történetekre fragmentálódott", és ezen belül, ezekhez a halmazokhoz képest kell müveiket elkészíteniük és elhelyezniük. ${ }^{3}$ Többen a kultúrtörténet-írást és a történetírás kulturális fordulatát említik kihívásként.

${ }^{1}$ Curran, James, Media and Power, London, New York, Routledge, 2006, (Az első kiadás éve: 2002 .) 4 .

${ }^{2}$ Michael Bailey, Su Holmes, Siân Nicholas, Tom O’Malley, Michael Bailey (ed.), Narrating Media History. Roundtable (= Roundtable $)=$ Media History, (16.), 2010/2, 243.

${ }^{3}$ Uo. 245. 
Azt látjuk tehát, hogy médiatörténeti tárgyú művek születnek a médiatörténet diszciplínáján belül, a történetírás kereti között, a médiatudomány és a társadalomtudományok úgynevezett történeti tanulmányai részeként (itt az önálló „history" és az egyes tudományterületek, például a médiatudomány, a szociológia vagy a politikatudomány részét jelentő „historical studies” megkülönböztetéséről van szó), ${ }^{4}$ továbbá bizonyos egyéb humán tudományok részeként. Azt is látjuk azonban, hogy ennek a szempontrendszernek az alapja egyfelől a téma, a kutató által alkalmazott módszer és elméleti modellek, valamint az adott tanulmányban, monográfiában fontosnak számító kérdés, másfelől a kutató, szerző identitása, (ön)besorolása - azaz az eltérő jellegü szempontok egyszerre való alkalmazása miatt módszertanilag nem túl megalapozott módon áll elő a médiatörténet mint diszciplína (pontosabban az ide sorolható mủvek halmaza). Ugyanakkor a médiatörténet-írás történetével foglalkozók ilyen módon járnak el, amikor érzékeltetni kívánják, hogy miféle erőteljes burjánzás tapasztalható „általában” a médiatörténet-írás „területein”. Még akkor is így tesznek, ha csak utalnak rá, vagy amikor megemlítik, hogy ez vagy az a médiatörténeti szempontból fontos monográfia történeti, de nem médiatörténeti jellegü. (Siân Nicholas hivatkozott írásában a médiatörténet-írás köztes pozícióját így határozta meg: ,a médiatörténet olyan hibrid múfaj, amely a médiatudomány és a történetírás, a társadalom- és a humán tudományok érintkezési felületén található".) ${ }^{5}$

A médiatörténet hibrid vagy interdiszciplináris jellegéből következik, hogy direkt módon is felmerül önállóságának kérdése. Hiszen valós dilemmának tünik, hogy ha a médiatörténet-írást egyrészt a tárgy, másrészt a saját módszertan (ide értve a modelleket is) határozza meg, akkor vajon nem egy olyan történeti tématerület-e „csupán”, ahol elsősorban a különféle társadalomtudományok müvelöit találjuk, lévén a szükséges módszertani ismeretekkel inkább ők rendelkeznek. ${ }^{6}$ Ezt a dilemmát felerősíti, hogy az olyan rendezvényeken, mint az Európai Kommunikációkutatási és Oktatási Társaság kongresszusai, a Kommunikációtörténeti Szekción kívül a Közönségkutatási Szekcióiban és másutt is rendszeresen tartanak történeti tárgyú előadásokat. Továbbá a médiatudományban fontos, sokat

${ }^{4}$ Simonson, Peter, PeCK, Janice, CRAIG, Robert T., JACKSON Jr., John P., Introduction = The Handbook of Communication History (= Communication History), New York, London, Routledge, 2013.

5 Roundtable, 243.

${ }^{6}$ A kérdés természetesen messze nem ilyen egyértelmü: a Klaus Bruhn Jensen szerkesztette módszertani kézikönyv (A Handbook of Media and Communication Research, Qualitative and Quantitative Methodologies [= Research], 2. kiadás, New York, Routledge, 2012.) egyrészt igazolja a módszertani ismeretekben való jártasságról mondottakat, viszont - érdekes módon - a történeti vizsgálatokról szóló fejezet (SCANnell, Paddy, History, media and communication) éppen módszertanilag nem túl megalapozott. Bill Kovarik monográfiájának (Revolutions in Communication, Media History from Gutenberg to the Digital Age, New York, Continuum, 2011.) bevezetöje - a történetírás objektivitásának kérdéséről szóló kétoldalas rész után - a média társadalomelméletéről közöl egy ennél is rövidebb összefoglalást, majd részletesebben tárgyalja a technológiai determinizmus kérdését, értelemszerüen McLuhan körül forogva. Az itt bemutatott koncepciók azonban a kötetben visszafogottan jönnek csak elö. 
idézett, újabb és újabb kutatásokat inspiráló kötetek között több is akad, amely történeti vizsgálatok eredményeit is tartalmazza, és nem csak „mellékesen”, a múltbeli előzményeket csupán kötelezően megemlítve. ${ }^{7}$

Ez átvezet a következő kérdéshez: a médiatörténet-írást vajon nem a kommunikációtörténet-írás részeként, alterületeként kellene szemlélnünk? Vagy esetleg média- és kommunikációtörténet-írás az „,egységes egész"?

A diszciplináris meghatározás nehézségei miatt tovább szúkítem az elemzés fókuszát: az egyszerüség kedvéért a szerzők, kutatók, szerkesztők, kiadók által médiatörténetinek nevezett írásokról szólok (például a Feminist Media History címü kötetről), függetlenül attól, hogy a szerzők történészek, médiatörténészek, médiakutatók vagy társadalomtudósok-e. Azért, hogy a vak véletlenen kívül más szervező elve is legyen írásomnak, ebből a termésből vitákat kiváltó munkákat, illetve olyan polémiákat mutatok be röviden, amelyek befolyásolják vagy befolyásolhatják a médiatörténet-írást mint gyakorlatot. Akár Magyarországon is.

A munkák ilyetén, tulajdonképpen a publikálás helyét alapul vevő besorolásának azonban az a következménye, hogy úgy tünhet: a médiatörténet-írás önálló diszciplína vagy legalábbis én ekként kezelem. Ugyanakkor egy-egy esetben eltérek ettől a szükítő eljárástól (ami, mint az előbb leszögeztem, a tudományterület értelmezését, észlelését is befolyásolja), és bizonyos témák kapcsán más diszciplínák vizsgálatait is megemlítem (vagy csak más, a médiatörténetre nem utaló címet viselő könyveket is felhozok példának). Ebben, ha nem is kizárólag, saját kutatási érdeklődésem befolyásol.

A médiatörténet-írás kiterjedésének eddig pertraktált problémái miatt nem általános leírást szeretnék adni a „diszciplína” helyzetéről (ahogy az angol nyelvü szakirodalom alapján látszik). Ehelyett kiválasztottam néhány kérdést, problémát, és azokat próbálom vázlatos módon bemutatni. Ezt annál inkább is megtehetem, mert magyar kutatók is írtak már médiatörténetről szóló historiográfiai, módszertani tanulmányt. ${ }^{9}$

${ }^{7}$ Erre jó példa Hallin, Daniel C., Mancini, Paolo, Comparing Media Systems, Three Models of Media and Politics, Cambridge, Cambridge University Press, 2004. Ennek a kötetnek hamar megjelent a magyar fordítása is (Médiarendszerek, A média- és politikai rendszerek három modellje, Budapest, AKTI, Gondolat, 2008.), köszönhetően az akkor még müködő Alkalmazott Kommunikációtudományi Intézetnek. Nem ilyen nagyhatású, de illusztratív példa: McNAIR, Brian, The Sociology of Journalism, London, Arnold, 1998.

8 Klaus Bruhn Jensen a média- és kommunikációtudomány története alapján arra a következtetésre jutott, hogy az 1980-as évektől kezdve e kettő konvergenciája zajlik, és ma már egy tudományterületként kell „róluk” beszélni. Ráadásul Maurice Merlea-Ponty az Észlelés fenomenológiája címü könyve nyomán az emberi testet (önmagában és eszközeivel együtt) a médiumok közé sorolja, ami tovább erősíti az egységes média- és kommunikációtudomány teóriáját. JENSEN, Klaus Bruhn, The state of convergence in media and communication research $=$ Research, $1-5$.

${ }^{9}$ A teljeség igénye nélkül, időrendben visszafelé haladva: Lipták Dorottya, Írjunk médiatörténeteket, de hogyan? Historiográfiai megközelités = Magyar Könyvszemle, 2014, 431-451.; LIPTÁK Dorottya, A modernkori könyv- és sajtótörténeti kutatások állapotáról (paradigmaváltás - problémafeltárás - alapelvek - programok - feladatok) = Magyar Tudomány, 2011, 1121-1131.; 


\section{Az elmélet szerepe: az újságírás- és médiatörténettöl a kultúrtörténetig}

Lehetséges, hogy a médiatörténet-írás a „médiatudomány nagypapája/nagymamája” és a „történetírás ivadéka” - de Nagy-Britanniára és az USA-ra gondolva tekinthetjük a sajtótörténet vagy az újságírás-történet valamiféle „továbbfejlődésének" is. A sajtótörténet az USA-ban és (elsősorban) Nagy-Britanniában politikatörténeti jellegü volt, és egyes újságok intézménytörténetét, egyes újságírók vagy laptulajdonosok biográfiáját jelentette. ${ }^{10}$ Fordulatot itt a társadalomtörténeti premisszák megjelenése eredményezett (ebből a szempontból Michael Schudson szociológiai tárgyú disszertációjának szerepét hangsúlyozzák), ami mára elvezetett oda, hogy a médiatörténetben a média társadalmi, intézményi és kognitív dimenzió lettek fontosak (erre még visszatérek). ${ }^{11}$

Az újságírás-történet helyzete problémásabbnak tünik, aminek az oka jelentős részben az, hogy az újságírás-tanulmányok (journalism studies) az egyetemi oktatás elkülönülő területe és emiatt valamiféle „zárvány” lett. James Carey 1974-es esszéjében, amely ma is a területről való gondolkodás kiindulási pontja, azt írta, hogy az újságírás-történet a klasszikus történetírás foglya, mégpedig ezért, mert teleologikus: ragaszkodik ahhoz a nagy elbeszéléshez, miszerint az újságírás története a kifejezés szabadsága irányába tartó „progresszív menetelés". (Ennek azonban elméleti vagy elméleti jellegü okai is vannak, mégpedig az úgynevezett normatív társadalomelméletek közé tartozó normatív médiaelmélet, amely szintén a demokrácia müködése felől nézve próbálja leírni a média - akár múltbeli, akár jelenbeli - müködését.) ${ }^{12} \mathrm{Az}$ újságírás-történeti kutatásokban az 1960-as évektől kezdve annyi változás következett be - így Carey -, hogy a nők és a kisebbségek is bekerültek, mert beleillettek ebbe a narratívába. ${ }^{13}$

Carey először több mint negyven éve megjelent tanulmányát azért tartják ma is aktuálisnak, mert az újságírás-történet tudományos hatása elhanyagolható,

Bajomi-LÁzÁr Péter, Média és társadalom, (2. kiadás.) Budapest, PrintXBudavár, Médiakutató Alapítvány, 2008, 13-18.; GYÁNI Gábor, Sajtótörténet a társadalomtörténész szempontjából = Médiakutató, 2006, 1, 57-64.; SzaJbéLy Mihály, A médiatörténet és a sajtótörténet viszonyáról = Médiakutató, 2005, 1, 71-79.; SzÉchenyi Ágnes, A huszadik század hiányzó magyar sajtótörténete, Adósságlista és javaslat = Magyar Tudomány, 2004, 1150-1163.; Sipos Balázs, Unter Disziplinen. Histrosche Medien- und Kommunikationsforschung in Ungarn = Medien und Zeit, 2003, 3, 8-22.

${ }^{10}$ Elég csak belenézni Stephen Koss monumentális munkájába: The Rise and Fall of the Political Press in Britain. I-II., Chapel Hill, London, The University of North Carolina Press, 1984.

1 Scannell 2012, i. m. 199.; Crowley, David, Heyer, Paul, Media = Communication History, New York, London, 58.

12 Christians, Clifford G., Glasser, Theodore L., McQuail, Denis, Nordenstreng, Kaarle, White, Robert A., Normative Theories of the Media. Journalism in Democratic Societies, Urbana, Chicago, University of Illinois, 2009.

13 Carey, James W., The Problem of Journalism History = The American Journalism History Reader, eds. Brennen, Bonnie, Hardt, Hanno, New York, Routledge, 2011, 22-27. 
mivel nincs nemzetközi horizontja, hanem parokiális, ${ }^{14}$ és mivel „izolálódott az akadémiai élettöl", amin csak az segíthet, ha tanul a kommunikáció- és a történettudománytól, a szociológiától, a kultúratudománytól, az antropológiától, a földrajz- és közgazdaságtudománytól. (És itt az útkereszteződés ismerős metaforájához értünk, miszerint az újságírás-történet a humán és társadalomtudományok kereszteződésében található ${ }^{15}$ - ahogy akár a médiatudomány, akár a médiatörténet-írás.) Azaz még mindig aktuálisnak tünik Carey problémafelvetése, a megújulásra vonatkozó ajánlata pedig időtállónak bizonyult. Ö ugyanis a Communication as Culture címú híres kötetében azokhoz csatlakozott, akik a kommunikációt mint kultúrát fogják fel. Meghatározása szerint „a kommunikáció szimbolikus folyamat, amelynek során a valóságot előállítják, fenntartják, javítják és átalakítják", ${ }^{16}$ ez pedig hasonló ahhoz, amit Raymond Williams írt a Long Revolution címü 1961-es munkájában: „a kommunikáció folyamata valójában a közösség müködése: a közös jelentések formálása, és ennek érdekében [végzett] közös cselekvések és célok". ${ }^{17}$

Careyre Williamsen kívül többek között hatott Clifford Geertz, akinek kultúra- és világkép-meghatározásában (,,a dolgok tiszta megjelenése [...], azaz a természetről, az énről, a társadalomról alkotott képzetek összessége [...] a rendről alkotott legáltalánosabb eszmék" ${ }^{18}$ szintén felfedezhető a kommunikáció szerepe, valamint hatott rá a brit kultúratudomány is. Rick Popp szerint éppen ez Carey aktualitásának a titka: munkássága illeszkedik a történetírás kulturális fordulatához, a kommunikáció új kultúrtörténetéhez, amely a kommunikáció befogadók gondolkodására gyakorolt hatását tartja fontos témájának. Azaz az újságírás kultúrtörténete a „fantáziadús világcsinálás” történeteként ma is érdekes. ${ }^{19}$

Visszatértünk tehát a következő dilemmához: mi a média-, a kommunikációés a kultúrtörténet-írás viszonya? Ebből a szempontból elsőként néhány kommunikációelméleti fejleményt kell megemlíteni, amelyek következményeit Roger Silverston így foglalt össze a Why Study the Media? címü 1999-es kötetében: a médiát a „tapasztalat általános szövetének” részeként kell tanulmányozni. A média „,[m]egszüri és keretbe foglalja a mindennapok valóságát a maga egyszeri és sokszoros reprezentációval, azzal, hogy mércét és viszonyítási pontot nyújt az életvezetéshez, a mindennapos tapasztalat létrehozásához és fenntartásához [...].

${ }^{14}$ Kovarik, Bill, Revolutions in Communication, Media History from Gutenberg to the Digital Age, New York, Continuum, 2011, 2-3.

15 Roessner, Amber, Popp, Ride, Creech, Brian, Blevens, Fred, „A Measure of Theory? ” Considering the Role of Theory in Media History = American Journalism, 2013, 2, 260, 262, 263.

${ }^{16}$ CARey, James W., Communication as Culture, Essays on Media and Society, Boston, Unwin Hyman, 1985, 23.

17 Williams, Raymond, Long Revolution, New York, Chatto \& Windus, 1961, 55.

18 Geertz, Clifford, Az ethosz, a világkép és a szent szimbólumok elemzése = Uö, Az értelmezés hatalma, Antropológiai írások, vál., utószó Niedermüller Péter, Budapest, Századvég, 1994, 5.

19 Roessner és mások elöbb hivatkozott cikke - a közös bevezetőt követően - egy-egy szerző által jegyzett fejezeteket tartalmaz. Popp fejezetének címe: Old Problems, New Problems: The Cultural Turn and Cultural History of Journalism. Idézet helye: 267-268. 
A média adja a szánkba a szavakat, amiket kiejtünk, a gondolatokat, amelyeket megfogalmazunk [...] egy olyan valóság részeként, amelyben magunk is részt veszünk, osztozunk, és amit magunk is fenntartunk mindennapos beszélgetéseinken, interakcióinkon keresztül." ${ }^{20}$

Látszik, hogy a kultúra antropológiai felfogása a médiatudományra is erőteljesen hatott, miközben az úgynevezett új kultúrtörténet-írás kialakulásának is egyik forrása volt (szoros összefüggésben a kultúratudomány megjelenésével). ${ }^{21}$ Ami még ezt az új paradigmát jellemzi, és szempontunkból fontos megemlíteni, az előbb a reprezentáció, majd a konstrukció koncepciójának a felértékelődése. Ennek a változásnak a hátterében - mint Peter Burke írja - az a felismerés található, hogy az ábrázolások és a szövegek nem csupán reflektálnak a valóságra, nem csupán utánozzák, hanem formálják, alkotják is. Így lettek témává a társadalmi valóság (ideértve például az európai identitást) diszkurzív konstrukciói, konstruálásai is. ${ }^{22}$

Ezen fejlemények alapján úgy tűnhet, hogy a médiatörténetnek a kommunikációtörténetben vagy a kultúrtörténetben, esetleg a kommunikáció kultúrtörténetében kellene feloldódnia. Valami hasonló a véleménye a már hivatkozott Klaus Bruhn Jensennek és a finn Raimo Salokangasnak. Előbbi egy 2002-es cikkében a médiatörténet kommunikációtörténetként való újraírása mellett tört lándzsát, amit (tudniillik a kommunikációtörténetet) interdiszciplináris és nyitott kultúratudományként írt le. Szerinte ugyanis a „második generációs történetek” (histories) már nem az adott médium szervezetével és produktumaival foglalkoznak, hanem túllépnek ezeken a kérdéseken. Fontosnak tartja továbbá az „alacsony” kultúra, pontosabban az ,ezen kulturális formák társadalmi terjesztéséért felelős” ágazat és intézmények vizsgálatát is. ${ }^{23}$ Jó példának két monográfit hoz fel - mint hangsúlyozza, egy irodalmár és egy történész munkáját, ami szerinte a hagyományos tudományok erejét, az interdiszciplináris nézőpontok iránti nagyobb nyitottságát mutatja. Az egyik Michael North Reading 1922: A Return to the Scene of the Modern címü kötete, amelyben a „magas” kultúra és a „széles kortárs kultúra” viszonyát elemezte, és arra jutott, hogy a kettő nem egymás ellentéteként határozható meg, mivel egyaránt részt vesznek ,a kulturális kifejezés és társadalmi interakciók esztétizációjában és formalizásában". ${ }^{24}$ A másik monográfia a történész Richard Butsch The Making of American Audiences: From Stage to Television, 1750-1990 címü kötete, amely szempontunkból nem csupán azért említésre méltó, mert az amerikai közönségek formálódásának története a populáris színháztól a televízióig, hanem a konstruálás ismerős koncepciója miatt is. (Ez a kettő

${ }^{20}$ Silverstone, Roger, Miért van szükség a média tanulmányozására?, Budapest, Akadémiai Kiadó, 2008, 20-21.

${ }^{21}$ Vö. Grifrin, Em, Bevezetés a kommunikációelméletbe, Budapest, Harmat Kiadó, 2003, 345-349.

${ }^{22}$ Burke, Peter, What is Cultural History? (2. kiadás.), Cambridge, Polity, 2008, 77-99.

23 Jensen, Klaus Bruhn, From Media History to Communication History, Three Comparative Perspectives on the Study of Culture = Nordicom Review, 2002, 1-2, 96.

${ }^{24}$ Uo. 97. 
egyébként más művekben is megfigyelhető; lásd például Daniel Czitrom, Laura Beers és James Curran írásait. $)^{25}$

Raimo Salokangasnak a Nordicom Review ugyanezen számában megjelent írása elméleti és gyakorlati szempontokat is felhoz. Az összehasonlító médiatörténet-írás lehetőségeit mérlegelve egyetértőleg hivatkozik Lennart Weibullra, aki megkülönböztette egymástól az összehasonlító leírásokat és az értelmező összehasonlításokat. Az előbbi jellemzője, hogy ugyanazokat a kérdéseket teszi fel, az utóbbié pedig az, hogy ,a média történelmi fejlődésének általános sémáiba ad betekintést, a fejlődést befolyásoló társadalmi erőkre fókuszálva". ${ }^{26}$ Ezt máshogy megfogalmazva Klaus Bruhn Jensen is leírja: az összehasonlító vizsgálatok menete eszerint a létező „,bizonyítékok” összegyüjtése, a feltárt adatsorok másodelemzése és értelmezése egy közös modellnek megfelelően. ${ }^{27}$ Azaz az „első generációs" történeti leírások eredményeinek valamilyen újrahasznosításáról van vagy lehetne szó. Ez viszont Salokangas egy másik gondolatára rímel, aki azt hangsúlyozza, hogy csak az egyes médiaintézmények müködését ismerve lehet továbblépni, rátérni a kultúrtörténeti szempontú vizsgálatokra, hiszen csak az intézményi logikákat ismerve tanulmányozható ,,a médiaszövegeket gyártó intézmények és a társadalom közötti csere". ${ }^{28} \mathrm{Az}$ ő javasolt kutatási menetrendje ennek megfelelően így néz ki: a médiumtörténetek után a médiatörténetnek (a médiarendszernek mint egésznek a története), majd az „általános kultúrtörténethez közelítö" kommunikációtörténetnek kellene következnie. Ebben egyetért az önmagát televízió-történészként meghatározó Su Holmes is. Rövid írásában fontosnak nevezte a „kronológiai fejlődést” a kutatásban, azaz - esetében - azt, hogy az intézménytörténet előzze meg a müfaj-, a szöveg-, a program- és a közönségelemzést. ${ }^{29}$

\section{Szintetikus és integrált médiatörténetek (gender-és politikatörténet)}

Az eddigi leírásból úgy tünhet, hogy az angol nyelvü médiatörténet-írás egyre inkább elméleti meghatározottságúvá válik, és egyre jobban közelít a „széles” kultúrtörténethez, az egységes kultúra felfogásához. Peter Burke egy korábbi leírása szerint ez azt jelenti: a kultúrtörténet-írásnak ,fel kell térképeznie az alapvetően létező kulturális egységet (de legalábbis az alapvető kapcsolatokat) anélkül,

${ }^{25}$ Czitrom, Daniel, Media and the American Mind. From Morse to McLuhan, Chappell Hill, University of North Carolina Press, 1983.; James CuRran, Media and the Making of British Society c. 1700-2000 = Media History, 2002, 2, 135-154.; BeErs, Laura, Your Britain, Media and the Making of the Labour Party, Cambridge, MA, Harvard University Press, 2010.

${ }^{26}$ Salokangas, Raimo, Media History Becomes Communication History - or Cultural History?

= Nordicom Review, 2002, 1-2, 101 .

${ }^{27}$ Uo. 96.

${ }^{28}$ Uo. 103.

${ }^{29}$ Roundtable, 237-238. 
hogy tagadná a múlt sokféleségét". ${ }^{30}$ Azaz az elitkultúra, a szubkultúrák és ellenkultúrák, a tömeg- és populáris (stb.) kultúrák olyasféle egységét, viszonyát kell feltárni, mint Michael North tette hivatkozott könyvében. Ez tehát több mint a populáris vagy tömegkultúrához sorolható médiaproduktumok vagy intézmények önálló vizsgálata, ami régóta fel-feltünik a médiatörténet területén. ${ }^{31}$

Az újabb angol nyelvü szakirodalmat olvasva mégis érzékelhetők viszonylag erőteljes kritikus hangok, amelyek nem egyszerủen az elméleti hiányosságokat tárgyalják (mint amit az újságírás-történet kapcsán láttunk), nem a kultúrtörténethez való közelítést hiányolják, hanem azt rögzítik: még az ezt megelőző lépcsőfokra se sikerült fellépni. Azaz jobbára még mindig egyes médiumok történetei, és nem médiatörténetek születnek. James Curran szerint ennek oka az, hogy a vizsgált médium típusa, illetve a hozzáférhető források és eltérő jellegük határozza meg a müvek karakterét, a feltett kérdéseket. ${ }^{32}$ Siân Nicholas 2012-ben szintén úgy vélte, hogy minden kísérlet ellenére is szeparált történetek születnek, mégpedig médium-típusok, médiatechnológiák szerinti sajtótörténetek, mozi- és filmtörténetek, valamint müsorszórás-, azaz rádió- és televízió-történetek. ${ }^{33}$ Eltérnek a kérdések is: a sajtótörténészeknek az intézményi fejlődés, a tulajdonlás, az elóállítás gazdaságtana, a sajtó politikai szerepe a fontos - és szerinte csak újabban az újságok társadalmi szerepe. A mozi/filmtörténészeket a kánon és a filmgyártás izgatja, továbbá a közönség társadalmi összetétele, a filmekben megjelenő kulturális tapasztalat és a populáris mozi. A rádió és TV brit történészeit az intézmények müködésén kívül a közönség, a kereskedelmi televíziók, a rádió és televízió helye a magánszférában (otthon), illetve a müsorszórók társadalmi szerepe érdekli. Nicholas ezeket az eltéréseket többek között a médiatípusok eltérő jellemzőivel magyarázza; azzal, hogy nagyon különböző érzékszervi élményeket kínálnak és nagyon különbözö környezetben. ${ }^{34}$

De milyen lehet a szintetikus médiatörténet? Nicholas javaslata szerint a kulcsfogalom az intermedialitás, ami a különféle médiumoktól egyaránt és kölcsönösen függő, egységes médiakultúra vizsgálatát jelenti. Azt hangsúlyozza, hogy a két világháború közötti Nagy-Britanniában létrejött egy „,professzionális tömegmédia-közösség" azokból a szereplőkből, akik többféle médium-típusnál is dolgoztak vagy ezekben feltűntek. Ilyenek például az újságokat reklámozó rádiósztárok, vagy a rádiós varietésorozatok szereplői, akik mozifilmekben is feltüntek. Fon-

${ }^{30}$ Burke, Peter, Varieties of Cultural History, Cambridge, Polity, 1997, 201.

${ }^{31}$ Shils, Edward, Mass society and its culture. [1961.] = Approaches to Media, A Reader, szerk. Oliver Boyd-Barrett, Chris Newbold, London, Arnold, 1995, 81-86.; Journalism and Popular Culture, szerk. Peter Dahlgren, Colin Sparks, London, Sage, 1992. (Ez a kötet jó példa az elmélet történetírásban való használatára is.) Vö. N. PARKER, Holt, Toward a Definition of Popular Culture = History and Theory, 2011, 2, 149-152.

32 Curran 2002, i. m. 135-136.

${ }^{33}$ Nicholas, Siân, Media History or Media Histories? Re-addressing the history of the mass media in inter-war Britain = Media History, 2012, 3-4, 18, 379.

${ }^{34}$ Uo. 384-385. 
tosnak tartja továbbá az 1930-as években jelentkező sajátos médiakonvergenciát is. Dan A. LeMahieut idézi, aki szerint az 1930-as évtized ,a konvergencia ideje a brit tömegmédiában”, amely változás egy széles, „közös” kultúra kialakulása irányába mutatott, és amelynek keretében az egyes médiumtípusok „,stílusokat és kommunikációs szemléletmódokat" vettek át egymástól. Az újságok új vizuális nyelvet kezdtek beszélni (ez az illusztrációkat és a layoutot egyaránt érintette), az újságírók rövidebb mondatokat és tömörebb bekezdéseket írtak, míg a tartalom konvergenciáját mutatja többek között a rádiómagazinok kiadása, valamint a rádió- és filmes rovatok megjelenése a lapokban, vagy például a magazin elnevezésének feltünése a rádióműsorok címében. Nicholas szerint a közönség is egységes jelenségként érzékelte a brit médiát. ${ }^{35}$

A szintetikus médiatörténetként említhető müvek közé tartozik Asa Briggs és Peter Burke magyarul is megjelent müve, A média társadalomtörténete Gutenbergtöl az internetig, ${ }^{36}$ Jean Chalabytól a The Invention of Journalism (London, Macmillan, 1998.), ahogy LeMahieu munkája is, a Culture for Democracy. Mass Communication and the Cultivated Mind in Interwar Britain (Oxford, Oxford University Press, 1988.). Utóbbit azért is említem, mert átvezet az úgynevezett integrált médiatörténet-írás területére, amely címkével azokat a müveket szokás jelölni, amelyek valamilyen nem médiatörténeti kontextusba ágyazva tárgyalnak médiatörténeti fejleményeket (ennyiben a kontextuális médiatörténet elnevezés is használható). ${ }^{37}$ Ilyen a politikai kultúra szempontjából megírt és már említett $\mathrm{Me}$ dia and the Making of the Labour Party, Laura Beers kötete, valamint Hallin és Mancini médiarendszerekről szóló monográfiája. Az amerikai „,politikatörténeti médiatörténetek" közül kiemelkedőnek tünik Paul Starr Pulitzer-díjas munkája, a The Creation of the Media: Political Origins of Modern Communications (New York, Basic Books, 2004.), többek között azért, mert - szakítva a technológiai determinizmus koncepciójával - a tágan értelmezett politikai változásokat, döntéseket tartja elsődlegesnek a média történetében (a politika fogalmához sorolja a politikai kultúrán kívül a gazdasági tényezőket is). Így például szerinte az Amerikai Egyesült Államok 20. századi globális médiahatalmának forrását a szabad sajtóról vallott 19. századi elvek jelentik, amelyek következménye, hogy az állam nem olyan módon vett részt a médiaipar működésében, mint például az Egyesült Királyságban tette. Ez vezetett a kommercializálódás nagyobb fokához, vagy ahhoz, hogy a távíróhálózat és a hírügynökségi rendszer üzleti alapon müködött. (Starr könyvének

35 Uo. 384-385, 389-390.

36 A kötetnek az első, illetve a javított és bővített második kiadása is megjelent magyarul (Budapest, Napvilág, 2004., 2012.). Erre 1. többek között TrÁDLER Henrietta recenzióját a Magyar Könyvszemle előző számában (2014, 507-509).

37 BAJOMI-LÁzÁR 2008, i. m. 14-15. (Az integrált és a szintetikus médiatörténet-írást olykor egymás szinonimáiként használják.) 
kritikusa ezen és más jellemzőkön kívül fontosnak tartja megjegyezni, és dicséri is, hogy a kötet nem az ,információs forradalom nyelvén” íródott.) ${ }^{38}$

$\mathrm{Az}$ integrált médiatörténet-írás népszerübbnek, elterjedtebb gyakorlatnak tünik, mint a szintetikus. Egyrészt azért, mert az első fogalmat olyan művek leírására is használhatjuk, amelyeket egy másik nézőpontból, nevezetesen az újságírás-történet felöl nézve az avítt munkák közé szokás sorolni. Mondjuk Edwin Emery maga korában népszerü sajtó- és újságírás-történeti monográfiája, a The Press and America. An Interpretive History of Journalism az amerikai politikatörténetbe ágyazza a lapok történetét, azaz ,integrált" médiatörténet - viszont Carey hivatkozott jellemzése is igaznak tünik rá. ${ }^{39}$ Másrészt népszerübbnek tünhet azért is, mert igen ismert és nagyhatású, számtalan kritikát kiváltó és sok kutatást inspiráló példa erre Jürgen Habermas monográfiája, A társadalmi nyilvánosság szerkezetváltozása.$^{40}$ És végül ezt mutatja James Curran jelentősebb visszhangot kiváltott munkája a brit médiatörténet-írásról. Curran ebben a 2002-es írásában (amely kötetének Rival Narratives of Media History címü fejezete) a brit médiatörténeti munkákat csoportosította, és arra jutott, hogy ezek néhány nagy narratívába illeszthetők. ${ }^{41}$ Öt klasszikusnak nevezett narratívát azonosított (plusz a technológiai deterministát, amelyet azonban elvetett): a liberálist, a feministát, a populistát, a libertariánust és az antropológiait, és úgy látta, hogy mind az öt az egyenes vonalú társadalmi haladást hangsúlyozza. Ezeken kívül még a radikális és a társadalomtörténeti elbeszélést mutatta be. ${ }^{42}$ Írása tehát - szerintem - az integrált médiatörténet sikerét mutatja (a szintetikushoz képest), annyiban mindenképpen, hogy ezek a narratívák majdnem mind a politikai, a kulturális és/vagy a társadalmi kontextusról szólnak. (Véleményemet megerősíti Siân Nicholas megjegyzése arról: a felosztás egyik problémája, hogy ezek a narratívák valójában a történetírás, és nem a médiatörténet-írás tanulmányozása alapján állnak elő. ${ }^{43}$ Ez pedig sokadszor a médiatörténet-írás diszciplináris helyének kérdését veti fel.)

E klasszifikáció hatására készült el a Narrating Media History címü tanulmánykötet, amely módszertani, historiográfiai írásokban (és szöveghelyeken) egyrészt Curran elgondolását járta körül, másrészt konkrét kutatási eredményeket

${ }^{38}$ Hampton, Mark, Media Studies and the Mainstreaming of Media History = Media History, 2005, 3, 242-243.

${ }^{39}$ A könyvet ma már alig használják, de a nekem meglévő példány a második kiadás 1964-es (harmadik) utánnyomása (Englewood Cliffs, Prentice Hall).

${ }^{40}$ Habermas, Jürgen, A társadalmi nyilvánosság szerkezetváltozása, Vizsgálódások a polgári társadalom egy kategóriájával kapcsolatban, Budapest, Osiris Kiadó, 1999. - Kritikájára 1. MátAY Mónika, Történészek Habermasról = Szociológiai Figyelö, 1999, 1-2. (http://www.c3.hu/ szf/ Szofi99/07/Szemezes-Fr.htm Utolsó letöltés: 2015. január 17.)

${ }^{41}$ Curran 2006, i. m. 3-53.

42 Részletesebben 1. Sipos Balázs, Sajtó és hatalom a Horthy-korszakban. (Politika-és társadalomtörténeti vázlat), Budapest, Argumentum Kiadó, 2011, 11-16.

${ }^{43}$ Roundtable, 243. 
közölt a felkínált narratíva-típusok szerinti rendben. ${ }^{44}$ A következő évben pedig a Media History címü folyóirat szervezett kerekasztalt a két kötet kapcsán.

A ,válasz-kötet” és a kerekasztal alapján azt mondhatjuk, hogy Curran kísérlete fontos, magyarázó erejü leírása a brit médiatörténet-írás történetének, a részletekben lakozó számtalan hibája ellenére is. Így felmerül, mondjuk az, hogy az azonosított narratívák erőteljesen átfedik egymást, hogy egyes nagy elbeszélések érvényességét esettanulmányok cáfolják, illetve fontos területek kimaradnak, azaz messze nem teljes az rendszer.

Nézzünk két példát! A kerekasztal első hozzászólója a „válasz-kötet” szerkesztője, Michael Baily volt, aki egy saját narratívát, koncepciót ajánlott (a hiányokat pótlandó), amely a technológia és a politika nézőpontját ötvözi. Javaslata szerint a médiatechnológiák valójában a kommunikáció olyan technológiái, amelyeket Foucault nyomán a „kormányzás kulturális technológiáiként” kellene értelmezni. Úgy fogalmaz: a médiatechnológiák fejlődése, előbukkanása „nem ok vagy tünet, hanem direkt kapcsolatban van a politikai racionalitások változásával, amelyek elsősorban azzal kapcsolatosak: hogyan lehet a legjobban kormányozni egy csoportot [...]" - és a 19. századi brit „technostate” példáját hozza fel, amely a közönség javára és szabályozására használta a kommunikációs technológiákat. ${ }^{45}$

Ugyancsak Baily munkája, de már a kötetből, a BBC korai évtizedeiről szóló tanulmány ${ }^{46}$ amelyet Curran feministanarratíva-leírása szerint így foglalhatnánk össze: a cél a női hallgatók fegyelmezése, a családi élet patriarchális szabályozásának támogatása volt. Ám másfelől az is felhozható, hogy a rádió müsoraiban azért szólította meg anyaként, háziasszonyként a hallgatókat, mert napközben ők voltak otthon, azaz elérhetők. Ráadásul mondhatjuk, hogy ezen a módon a BBC nyilvánosan mutatott be a nyilvános térben nem látszódó szereplőket (háziaszszonyokat) és cselekvéseket (házimunkákat). Ráadásul - mint Baily hangsúlyozza - nem csupán társadalmi nemi, hanem osztályalapon is leírható ez a történet, amennyiben a munkásosztálybeli háziasszonyoknak mutatták meg a háztartásszervezés középosztálybeli ideálját. ${ }^{47}$

Ezen a ponton igen röviden külön is kitérnék a nötörténet és a médiatörténet-írás viszonyára. Ebben kutatói érdeklődésemen és a téma fontosságán kívül egy 2011-es kötet játszik szerepet, amely újra rávilágít a médiatörténet-írás gyakorlatainak sokszínüségére és a diszciplína körülhatárolásának nehézségeire.

A nőtörténeti szempontú médiatörténet esetében tulajdonképpen újra azokkal a nehézségekkel találkozhatunk, amelyek a médiatörténet mint tudományterület kialakulását és helykeresését - a cikkem elején idézett leírások szerint-jellemezték és jellemzik. Az első probléma a téma fontossá nyilvánítása a történeti témák között. Itt mintha a médiatörténet-írás bizonyos elmaradását kellene rögzíteni

${ }^{44}$ Narrating Media History, szerk. Michael Baily, London, New York, Routledge, 2009.

45 Roundtable, 235.

${ }^{46}$ BAILY, Michael, The angel in the ether, Early radio and the constitution of the household= Uö 2009, i. m. 52-65.

47 Uo. 60. 
a kultúrtörténet-íráshoz képest. Legalábbis a hivatkozott kommunikációtörténeti kézikönyv „Gender és média” részének szerzője, Karen Ross szerint „A társadalmi nemek és média nagyon új aldiszciplína, mert a nemek politikai konfliktusa és médiabeli megnyilvánulásuk csak újabban lett elismert tudományos téma." A gender és média története témáján belül olyan területek hangsúlyosak, mint a nők (és férfiak) szerepe a médiaiparban, a „tartalom-előállításban”, a nők (és férfiak) médiafogyasztása, illetve a nők (és férfiak) médiaábrázolása. ${ }^{48}$

A második ,problémát” az jelenti, hogy ebben az esetben a társadalmi nemek tanulmánya és/vagy a feminista tanulmányok is felsorakoznak a határtudományok között. Ennek következményeként újra azt tapasztalhatjuk, hogy a más tudományok müvelői írnak historiográfiai szempontból fontos műveket a média történetéről. Ezek jobbára illenek ugyan Curran feministanarratíva-kategóriájába, és így akár mondhatjuk is, hogy integrált médiatörténetek, de csak azzal a több mint „erőteljes megszorítással”, hogy valójában nem médiatörténetiek. ${ }^{49}$

Maria Di Cenzo, Lucy Deap és Leila Ryann feminista médiatörténetének bevezetöje ezt rögzíti: a médiatörténet a történetírás és a társadalomtudományok (médiatudomány) közötti „szakadékból” nőtt ki - és a feminista médiatörténettel is ez a helyzet. Ez a mostanra mégis kiformálódó terület a politikatörténet-írás és a kultúrtörténet-írás számára is sok újdonságot hozhat. Amint a szerzők is hangsúlyozzák: a hagyományos diszciplínák hipotéziseinek és narratíváinak újraírását eredményezheti. ${ }^{50}$ (Erre jó példa már önmagában az is, hogy az elemzett női lapoknak a politika intézményi világán kívülről sikerült újradefiniálniuk a politika (politics) témáját, azaz a határait kiterjeszteni.)

\section{Összefoglalás}

Írásom végén újra szeretnék aláhúzni néhány állítást. A médiatörténet-írás az angol nyelvü, elsősorban brit és egyesült államokbeli szakirodalmat szemlélve erösen elméleti jellegü - vagy legalábbis határozott az erre való törekvés. Ezzel függ össze, hogy az egyes intézmények története helyett az integrált vagy szintetikus médiatörténet-írás számít újnak, divatosnak: ez lehet a média mint rendszer egységes vizsgálata (a saját kutatás kombinálása mások eredményeinek másodelemzésével), azaz valamiféle szintézis, lehet más „(al)rendszerekbe” való integrálás, és lehet a kultúratudomány, az új kultúrtörténet vagy a kommunikáció kultúrtörténete irányába való elmozdulás (sürgetése). A sokszínüség további oka,

${ }^{48}$ Ross, Karen, Gender and Media, A Very Short Herstory = Communication History, 347, 355.

${ }^{49}$ Erre 1. Sipos Balázs, Modern amerikai lány, új nö és magyar asszony a Horthy-korban, Egy nötörténeti szempontú médiatörténeti vizsgálat = Századok, 2004, 3-8.

${ }^{50}$ Di Cenzo, Maria, Deap, Lucy, Ryann, Leila, Feminist Media History. Suffrage, Periodicals and the Public Sphere, Hampshire, Palgrave Mcmillan, 2011, 4. - A kötet médiatörténeti értelmezésére 1. Sowon S. PARK (Media History, 2012, 1, 109-110.) és Jane MARCELLus recenzióját (American Journalism, 2013, 2, 287-289.). 
hogy a médiatörténet mint tématerület és a médiatörténet-írás mint diszciplináris gyakorlat nem esik egybe, mivel igen sok a szóba jöhető - mondjuk úgy - határtudomány. Utóbbi a magyarázata annak, hogy nagyon eltérő elméleti hagyományokkal és koncepciókkal találkozhatunk. Ez írásomból kevéssé érződött. Nem szóltam továbbá a tudományok hibridizációjának olyan következményeiről se, mint az úgynevezett médiaarcheológia. Nem említettem olyan módszertani változásokat se, mint amilyenek az oral history alkalmazásában ${ }^{51}$ vagy a történeti közönségkutatásban zajlottak, zajlanak..$^{52} \mathrm{Nem}$ említettem vagy nem tárgyaltam önállóan néhány olyan témát, amellyel pedig Magyarországon is foglalkoznak: ilyen például a vizuális reprezentációk szerepe bizonyos valóság-konstrukciókban,,$^{53}$ az információtörténet-írás, ${ }^{54}$ a média gazdaságtörténete, ${ }^{55}$ a propaganda-történet ${ }^{56}$ vagy az újságírás politika-, társadalom- és kultúrtörténetbe ágyazott története. ${ }^{57}$

Az ilyesféle szemlék kapcsán óhatatlanul is felmerül a kérdés, hogy hol tart ehhez képest a magyarországi médiatörténet-írás. Az elszórt hivatkozások azt mutatják, hogy a hazai médiatörténet-írás reflexív, követni igyekszik bizonyos nemzetközi trendeket, annak ellenére is, hogy az intézményesítés és az intézményesített támogatás szempontjából (olykor tudománypolitikai okok miatt) marginális, kiszolgáltatott helyzetben van. Mindezek miatt az a benyomásom, hogy a magyarországi médiatörténet-írás állapota jobb, mint a feltételei, amit a felsőoktatástól az OTKA-ig tartó intézményrendszer határoz meg.

${ }^{51}$ Röviden 1. Sipos Balázs, Médiatörténet és az elbeszélt történelem $=$ A rendszerváltás és az újságírók, szerk. Bajomi-Lázár Péter, Monori Áron, Budapest, PrintXBudavár, Médiakutató Alapítvány, 2007, 361-364.

${ }^{52}$ Röviden 1. SIPos Balázs, Világ-képek, kulturális regiszterek és Amerika jelenléte a Horthy-korban: A transznacionális és kapcsolati történetírás adaptálásának lehetöségeiröl $=N y i t o t t / z a ́ r t ~ M a-$ gyarország: Politikai és kulturális orientáció 1914-1949, szerk. Feitl István, Budapest, Napvilág Kiadó, 2013, 154-156.

${ }^{53}$ L. például BuzinKay Géza, Nemzeti sztereotipiák politikai müködése, Dualizmus-kori osztrák és magyar karikatúrák egymásról = Cito pede labitur aetas: tanulmányok Kapronczay Károly 70. születésnapjára, szerk. Magyar László András, Kapronczay Katalin, Budapest, Semmelweis, 2011, 69-80.; TAmÁs Ágnes, Vizuális percepciók a Nagy Háborúról a hatalom szürőjén keresztül = Aetas, 2014, 3, 59-77.; Ujvári Hedvig, Testi (sz)épség: Az „izomzsidó” fogalma Max Nordaunál a fin de siècle kontextusában = Századok, 2009, 143-160.

${ }^{54}$ L. Z. Karvalics László, Horizontokat tágitó és civilizáló erő, Az információtörténeti fordulat irányairól és esélyeiröl a sajtótörténet-irásban = Médiakutató, 2014, 2, 7-15.

55 L. például Balogh János Mátyás, A Lloyd-mechanizmus, Krízis és árpolitika a lapkiadásban (1860-as és 1870-es évek) $=$ Korall, 2013, 54, 43-62.

${ }^{56}$ L. például Vörös Boldizsár, Történelemhamisitás és politikai propaganda, Illés Béla elmeszüleményei a magyar szabadságküzdelmek orosz támogatásáról, Budapest, MTA Bölcsészettudományi Kutatóközpont Történettudományi Intézet, 2014.

${ }^{57}$ L. például TAKÁCs Róbert, Politikai újságírás a Kádár-korban, Budapest, Napvilág Kiadó, 2012.; BuzinKay Géza, A bünügyi hir, a riporter és a rendör $=$ Budapesti Negyed, 2005, 1-2, 7-28.; Sipos Balázs, A politikai újságírás mint hivatás, Nyilvánosság, polgári sajtó és a hírlapirók a Horthykorszak elsö felében, Budapest, Napvilág Kiadó, 2004. 